\title{
PERAN MOTIVASI KERJA DALAM MEMODERASI PENGARUH KEPUASAN KERJA KARYAWAN DAN KOMITMEN ORGANISASI TERHADAP KINERJA KARYAWAN PT. PLN (PERSERO)
}

\author{
Hartiwi Prabowo; Vana Lestari \\ Management Department, School of Business Management, BINUS University \\ Jln. K.H. Syahdan No. 9, Palmerah, Jakarta barat 11480 \\ Hartiwi2200@binus.ac.id
}

\begin{abstract}
Employee performance is a major factor determining organizational success. Various complaints that arise related to power outages and high electricity tariff increase people demand as consumers on excellent service. Total consumers of PLN Disjaya reach 3,759,546 subscribers (March 2011), it is one unit that has the largest number of subscribers compared to other PLN units, and also provides the largest contribution to revenue. On a survey of Integrity, PLN Disjaya service from 2006 to 2010 showed that over the last five years, PLN Disjaya integrity is below target. The purpose of this study is to analyze the role of motivation in moderating influence between job satisfaction and organizational commitment partially and simultaneously on employee performance. Data collection techniques used questionnaires to 160 employees as respondents; data analysis techniques used Regresion Moderated Analysis (MRA). The results showed the role of motivation can moderate the job satisfaction on employee performance, but by individual motivation cannot moderate the commitment to employee performance.
\end{abstract}

Keywords: motivation, job satisfaction, commitment, employee performance

\begin{abstract}
ABSTRAK
Kinerja karyawan merupakan faktor utama yang menentukan keberhasilan organisasional. Berbagai keluhan masyarakat yang muncul terkait dengan pemadaman listrik dan tingginya tarif dasar listrik, memperbesar tuntutan masyarakat sebagai konsumen akan pelayanan prima. Total konsumen PLN Disjaya mencapai 3.759.546 pelanggan (Maret 2011), yang merupakan salah satu unit yang memiliki jumlah pelanggan terbesar dibandingkan dengan unit-unit lain PLN, dan juga memberikan kontribusi terbesar bagi pendapatan PLN. Survei Integritas pelayanan PLN Disjaya dari 2006 sampai 2010 memperlihatkan bahwa selama lima tahun terakhir, intergritas PLN Disjaya masih berada di bawah target. Tujuan penelitian ini untuk menganalisis peran motivasi kerja dalam memoderasi pengaruh antara kepuasan kerja dan komitmen organisasi secara parsial dan simultan terhadap kinerja karyawan. Teknik pengumpulan data menggunakan kuesioner terhadap 160 karyawan sebagai responden, teknik analisis data menggunakan Moderated Regresion Analysis (MRA). Hasil penelitian menunjukkan peran motivasi kerja memoderasi kepuasan kerja terhadap kinerja karyawan, namun secara individual motivator kerja tidak dapat memoderasi komitmen terhadap kinreja karyawan.
\end{abstract}

Kata kunci: motivasi, kepuasan kerja, komitmen, kinerja karyawan 


\section{PENDAHULUAN}

Di sebagian besar organisasi, kinerja individual karyawan merupakan faktor utama yang menentukan keberhasilan organisasi. Diskusi tentang jenis pekerjaan dan menjadi seorang pemberi kerja menekankan bahwa seberapa baik para karyawan melakukan pekerjaan mereka memengaruhi kinerja organisasional secara signifikan (Mathis dan Jackson, 2006).

Don Carew, Fay Kandarian, Eunice Parisi-Carew, dan Jesse Stoner (2000) dalam WK, Chong, dan William (2010) melakukan sebuah riset intensif untuk mendefinisikan dan mengidentifikasikan nilai-nilai sebuah perusahaan berkinerja tinggi. Sebagai hasil dari riset mereka, Don Carew, Kandarian, Parisi Carew, dan Stoner (2000) menciptakan "SCORES" perusahaan berkinerja tinggi. "SCORES" adalah sebuah singkatan yang mewakili enam buah elemen yang menjadi syarat di setiap perusahaan berkinerja tinggi, yaitu: (1) Shared Information and Open Communication (Informasi yang Terdistribusi dan Komunikasi yang Terbuka), (2) Compelling Vision (Visi yang Meyakinkan), (3) On going Learning (Pembelajaran Berkelanjutan), (4) Relentless Focus on Customer Results (Fokus tanpa Henti kepada Kepuasan Pelanggan), (5) Energizing Systems and Structure (Sistem dan Struktur yang Memberi Semangat), (6) Shared and Power and High Involvement (Kekuasaan yang Diditribusikan dan Keterlibatan Tinggi).

PT. PLN (Persero) merupakan suatu badan yang bergerak di bidang kelistrikan yang melayani kebutuhan akan tenaga listrik untuk berbagai lapisan masyarakat Indonesia mulai dari industri hingga rumah tangga. Sebagai satu-satunya perusahaan yang memasok listrik di Indonesia, PT. PLN yang berpegang teguh pada visi, "Diakui sebagai Perusahaan Kelas Dunia yang Bertumbuh-kembang, Unggul, dan Terpercaya dengan bertumpu pada Potensi Insani”, memiliki tantangan yang semakin kompleks dewasa ini.

Berbagai keluhan masyarakat yang muncul terkait dengan pemadaman listrik, tingginya tarif dasar listrik, memperbesar tuntutan masyarakat sebagai konsumen akan pelayanan prima. Total konsumen PLN Disjaya mencapai 3.759.546 pelanggan (Maret, 2011), merupakan salah satu unit yang memiliki jumlah pelanggan terbesar dibandingkan dengan unit-unit PLN lainnya, dan juga memberikan kontribusi terbesar bagi pendapatan PLN. Kontribusi pendapatan yang diberikan melebihi Rp.23 triliun. Dengan demikian PLN Disjaya menjadi salah-satu unit yang strategis bagi PLN secara keseluruhan.

Keberhasilan PLN Disjaya dalam memenuhi misinya dapat dikatakan sebagai indikator dari kinerja perusahaan tersebut, salah satunya terlihat dari pemenuhan konsumsi listrik nasional. Sampai saat ini rasio elektrifikasi PLN Disjaya untuk wilayah distribusi Jakarta Raya dan Tangerang sudah mencapai lebih dari 88\% secara nasional (status data tahun 2008, www.pln.co.id). Berdasarkan data tersebut, dapat disimpulkan bahwa PLN Disjaya sudah cukup mampu memenuhi target pemenuhan konsumsi listrik.

Namun pada taraf pelayanan pelanggan, kepuasan masyarakat terhadap pelayanan PLN Disjaya belum memuaskan. Hal ini dapat diketahui dari data ketidakpuasan pelanggan melalui metode survei yang dilakukan oleh pihak independen untuk tahun 2010 oleh PUSKAPOL (Pusat Kajian Politik FISIP) UI, dengan memetakan kepuasan dan ketidakpuasan pelanggan, dan hasilnya sebagaimana diuraikan pada gambar berikut. 


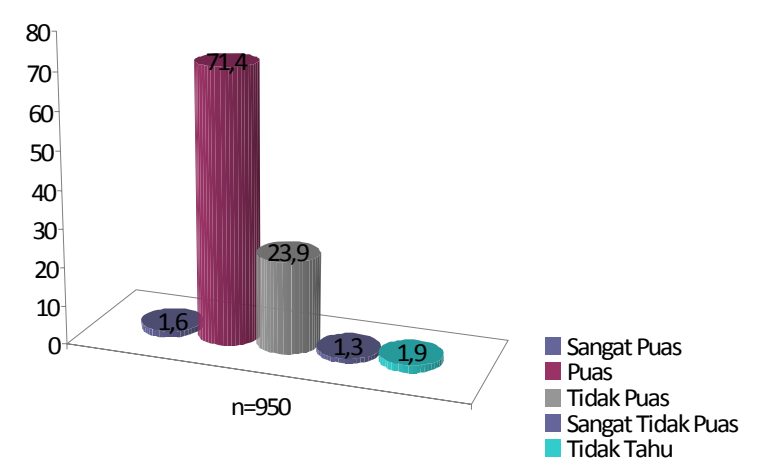

Gambar 1 Grafik Kepuasan Pelanggan tahun 2010

(Sumber: PT. PLN (Persero) Disjaya dan Tangerang)

Grafik tersebut menunjukkan bahwa 23,9\% pelanggan tidak puas dengan pelayanan PLN Disjaya. Persentase ketidakpuasan pelanggan ini meningkat menjadi 41,87\% di tahun 2011 berdasarkan hasil survei ketidakpuasan pelanggan yang dilakukan PLN Disjaya dengan menggandeng PUSKAPOL (Pusat Kajian Politik FISIP) UI sebagai konsultan (www.pln.co.id/disjaya).

Selain itu, hasil survei integritas pelayanan pelanggan lima tahun terakhir mulai dari 2006 sampai 2010 yang terdiri dari pengalaman integritas (pengalaman korupsi, cara pandang terhadap korupsi), potensi integritas (lingkungan kerja, sistem administrasi, perilaku individu, dan pencegahan korupsi) memperlihatkan bahwa PLN termasuk 15 instansi dengan integritas paling buruk (Lampiran surat No. 024/480/DISJAYA/2010). Berikut data survei Integritas pelayanan PLN Disjaya dari 2006 sampai 2010 yang memperlihatkan bahwa selama lima tahun terakhir, intergritas PLN Disjaya masih berada di bawah target.

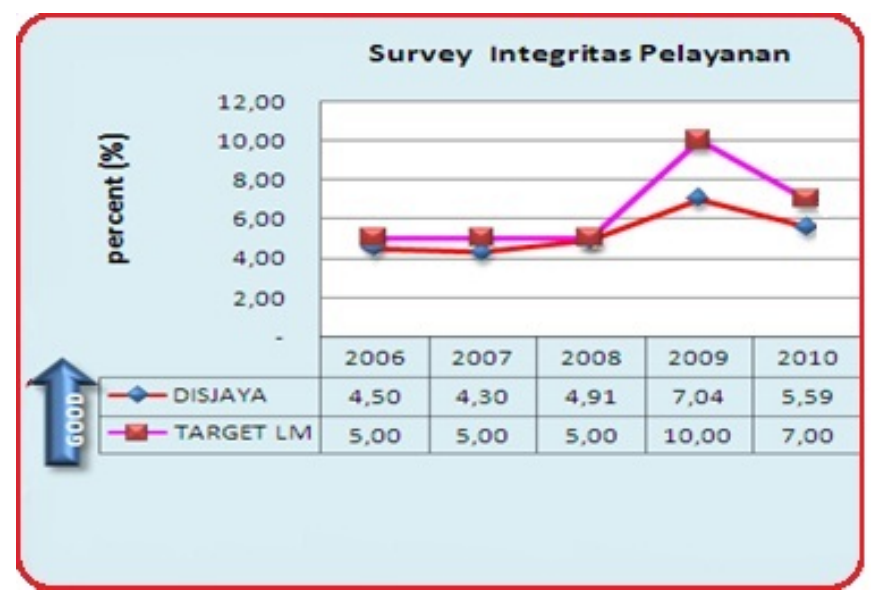

Gambar 2 Grafik Survei Integritas Pelayanan (Sumber: PT. PLN (Persero) Disjaya dan Tangerang)

Beberapa data di atas menunjukkan bahwa kinerja karyawan PLN Disjaya belum optimal untuk memenuhi kepuasan pelanggan. Sementara itu, kepuasan pelanggan yang tinggi dapat dicapai apabila karyawan memberikan totalitas pelayanan terhadap pelanggan. Oleh karena itu, PLN Disjaya perlu meningkatkan kinerja SDM yang dimilikinya. Hal tersebut menjadi sebuah tuntutan yang harus dipenuhi karena kinerja SDM erat kaitannya dengan pencapaian kinerja perusahaan secara keseluruhan. Untuk mencapai hal tersebut, maka upaya PLN Disjaya perlu didukung oleh motivasi bekerja, komitmen terhadap organisasi, dan kepuasan kerja yang tinggi dari para karyawannya 
sehingga dapat meningkatkan kinerja karyawan dalam mencapai tujuan suatu organisasi. Tujuan penelitian ini untuk menganalisis peran motivasi kerja dalam memoderasi pengaruh antara kepuasan kerja dan komitmen organisasi secara parsial dan simultan terhadap kinerja karyawan.

\section{Hubungan Motivasi Kerja, Kepuasan Kerja, dan Kinerja Karyawan}

Motivasi adalah kemauan untuk memberikan upaya lebih untuk meraih tujuan organisasi, yang disebabkan oleh kemauan untuk memuaskan kebutuhan individual (Robbins, 2007). Motivasi yang tinggi akan menciptakan sebuah komitmen terhadap yang menjadi tanggung jawabnya dalam menyelesaikan setiap pekerjaan (McNeese-Smith et al, 1995 dalam Devi, 2009). Karyawan dengan tingkat motivasi yang tinggi juga di nilai memiliki hubungan yang searah dengan kepuasan kerja sehingga berdampak pada peningkatan produktivitas dan kreativitas (Amabile,1996; Amabile dan Kramer, 2007 dalam Joo dan Lim, 2009).

Di sisi lain, kepuasan kerja mengacu pada sikap umum karyawan terhadap pekerjaannya. Karyawan yang kepuasan kerjanya tinggi akan bersikap positif terhadap pekerjaannya, sedangkan karyawan yang kecewa terhadap pekerjaannya akan bersikap negatif (Robbins, 2007). Salah satu masalah kontroversial dalam kepuasan kerja adalah hubungannya dengan kinerja kerja. Bertahuntahun yang lalu, penelitian mengindikasikan hubungan yang lemah antara kepuasan dan kinerja dengan nilai korelasi hanya sebesar 0,15 (Iaffaldano dan Muchinsky, 1985) dalam Kim (2005). Namun, analisis konseptual dan metodologi empiris dan praktis memperdebatkan hasil tersebut. Penelitian yang dilakukan (Heskett, et al. 1994 dan Way, Sturman, dan Raab 2010) menunjukkan bahwa dengan meningkatkan kepuasan kerja karyawan dapat menjadikan kinerja karyawan sekaligus kinerja organisasi lebih baik.

Selain itu, sebuah Meta-Analisis yang lebih rumit dilakukan oleh Tim Jugde dan rekannya (2001) dengan menggunakan 312 sampel dan kombinasi $N$ 54,417 menemukan korelasi sebenarnya menjadi 0,30. Dengan demikian, hasil analisis ini menunjukkan hubungan yang jauh lebih kuat antara kepuasan kerja dan kinerja karyawan. Kaitan kepuasan kerja dengan kinerja karyawan juga dikemukakan oleh Ostroff (1992) yang ditunjukkan oleh keadaan perusahaan dengan karyawan yang lebih terpuaskan cenderung lebih efektif daripada perusahaan-perusahaan dengan karyawan yang kurang terpuaskan. Begitu pula hasil penelitian dari McNeese-Smith (1996) dalam Devi (2009) yang menunjukkan hubungan antara kepuasan kerja yang berpengaruh signifikan dan positif terhadap kinerja karyawan (berkorelasi $r=0.25$ dan $p=0.001$ ). Berdasarkan beberapa penelitian tersebut, maka

hipotesis 1: kepuasan kerja berpengaruh langsung, positif dan signifikan terhadap kinerja karyawan.

Sejauh ini cara yang paling umum menyelidiki hubungan kepuasan kerja dan kinerja kerja adalah dengan melibatkan penggunaan variabel moderator. Locke (1970) berhipotesis bahwa pencapaian nilai akan memoderasi hubungan kepuasan kerja dan kinerja. Imbalan hanya salah satu jenis dari banyaknya penghargaan pada pekerjaan, dan penelitian menunjukkan korelasi yang lemah antara gaji dan kepuasan kerja (Spector, 1997 dalam Judge, 2001). Karyawan lebih menghargai penghargaan intrinsik seperti sifat dari pekerjaan itu sendiri dari pada imbalan yang akan mereka terima (Jurgensen, 1978).

Menurut Hersey dan Blanchard (1988) dalam Hong dan Waheed, (2011), motivasi dan kepuasan merupakan suatu hal yang sangat berbeda dalam hal penghargaan (reward) dan kinerja. Para peneliti menunjukkan motivasi merupakan konsekuensi dari harapan masa depan sedangkan kepuasan merupakan konsekuensi dari peristiwa masa lalu (Carr, 2005 dalam Hong dan Waheed, 2011). Huselid (1995) dalam Hong dan Waheed (2011) percaya bahwa jika pekerja tidak termotivasi, turnover akan meningkat dan karyawan akan menjadi frustrasi dan tidak produktif. Berbagai peneliti lain yang telah menyelidiki motivasi dan kepuasan kerja juga mendukung pernyataan tersebut (Robbins, 2007; Parsons dan Broadbridge, 2006). Oleh karena itu, motivasi dan kepuasan tidak identik dengan satu 
sama lain. Sangat penting untuk menjelaskan perbedaan konsep antara motivasi dan kepuasan sehingga lebih mudah untuk memahami bahwa motivasi mengarah ke kepuasan, yang akhirnya mengarah pada peningkatan kinerja (Hong dan Waheed, 2011). Dengan demikian,

hipotesis 2: $\quad$ motivasi kerja dapat memoderasi pengaruh variabel kepuasan kerja terhadap variabel kinerja karyawan.

\section{Hubungan Komitmen Organisasi, Motivasi Kerja, dan Kinerja Karyawan}

Komitmen organisasi didefinisikan oleh beberapa peneliti sebagai ukuran dari kekuatan identitas dan keterlibatan karyawan dalam tujuan dan nilai-nilai organisasi. Komitmen organisasi didapatkan sebagai indikator yang lebih baik dari "leavers" dan "stayers" daripada kepuasan kerja (Porter, Steers, Mowday, dan Boulian, 1974, dalam McNeese-Smith, 1996 dalam Nurjanah, 2008).

Allen dan Meyer dalam Luthans (2006) mendefinisikan komitmen organisasi sebagai berikut: "Komitmen organisasi merupakan keyakinan yang menjadi pengikat seseorang dengan organisasi tempatnya bekerja yang ditunjukkan dengan adanya loyalitas, keterlibatan dalam pekerjaan dan identifikasi terhadap nilai-nilai tujuan organisasi”. Dalam sebuah organisasi, ikatan batin antara karyawan dengan organisasi dapat dibangun dengan menyamakan misi, visi, dan tujuan organisasi, bukan sekedar ikatan kerja. Sehingga bila setiap karyawan memiliki komitmen yang kuat untuk memberikan prestasi terbaiknya, maka tentunya kinerja organisasi akan meningkat.

Banyak penelitian organisasi dan manajer menaruh perhatian khusus pada komitmen organisasi dengan keyakinan bahwa organisasi dengan karyawan yang berkomitmen akan meraih kinerja yang superior dalam waktu yang lama (Bentein, et al. 2005; Jaros, et al. 1993; Luchak dan Gellatly 2007; Meyer, Becker, dan Vdanenberghe 2004). Hal ini didukung oleh Harrison dan Hubard (1998) dalam Devi (2009) yang menyatakan bahwa karyawan yang memiliki keterlibatan tinggi dalam bekerja (komitmen) tidak mempunyai keinginan untuk keluar dari perusahaan dan ini merupakan modal dasar untuk mendorong produktivitas ke arah yang lebih tinggi. Dengan demikian diperoleh

hipotesis 3: variabel komitmen organisasi memiliki pengaruh langsung, positif dan signif terhadap variabel kinerja karyawan.

Begitu juga dengan penelitian yang dilakukan McNeese - Smith (1996) dalam Devi (2009) yang mengungkapkan bahwa komitmen karyawan terhadap organisasi yang tinggi akan berpengaruh terhadap kinerja karyawan (berkorelasi $r=0.31$ dan $p=0$.001). Adanya komitmen yang tepat akan memberikan motivasi yang tinggi dan memberikan dampak yang positif terhadap kinerja suatu pekerjaan.

Penelitian yang dilakukan oleh Nyhan (1999) dalam Astuti (2005) terhadap pegawai pemerintah mengungkapkan bahwa komitmen karyawan pada organisasi disamakan dengan motivasi untuk memberikan layanan terhadap masyarakat yang dimiliki pegawai pemerintah. Sekaligus menjadikan komitmen organisasi bernilai bagi efektifitas organisasi. Hal ini sejalan dengan yang dikemukakan Romeck (1990) dalam Astuti (2005) bahwa karyawan yang memiliki komitmen organisasi yang tinggi akan lebih termotivasi untuk hadir dalam organisasi dan berusaha mencapai tujuan organisasi.

Dari sudut pandang motivasi, komitmen organisasi secara teoretis berasosiasi dengan kinerja karyawan (Hunt, et al., 1985, Birnbaum dan Somers, 1998) dalam Samad (2011). Sebagai contoh, sifat dasar dari motivasi adalah dorongan untuk bertindak ke arah pencapaian tujuan (Steers, 1977) dalam Decotiis dan Summers (1987) dan satu ataupun banyak tujuan masih termasuk ke dalam tujuan organisasi. Oleh karena itu, motivasi dapat dipandang sebagai komitmen untuk mencapai tujuan 
organisasi. Penelitian (Lee, 1971 ; Mowday, 1979) dalam Decotiis dan Summers (1987) menunjukkan bahwa karyawan yang memiliki komitmen tinggi terhadap organisasi biasanya lebih termotivasi dan produktif.

Namun, menurut penelitian empiris Ingram, et al. (1989) dan Sager dan Johnston (1989) dalam Samad (2011) menyatakan bahwa komitmen organisasi dan kinerja karyawan memiliki hubungan yang sangat kecil. Begitu juga dengan penelitian Mathieu dan Zajac (1990) yang menemukan bahwa korelasi antara komitmen organisasi dan kinerja karyawan relatif rendah tetapi positif. Jadi, komitmen organisasi dalam hal ini mungkin berhubungan dengan beberapa personal outcomes, tetapi sifat hubungannya masih harus diteliti lebih lanjut (Decotiis dan Summers, 1987).

Dari sini diperoleh

hipotesis 4: variabel motivasi kerja dapat memoderasi hubungan antara variabel komitmen organisasi terhadap variabel kinerja karyawan, dan

hipotesis 5: variabel kepuasan kerja dan komitmen organisasi memiliki pengaruh simultan, positif dan signifikan terhadap variabel kinerja karyawan.

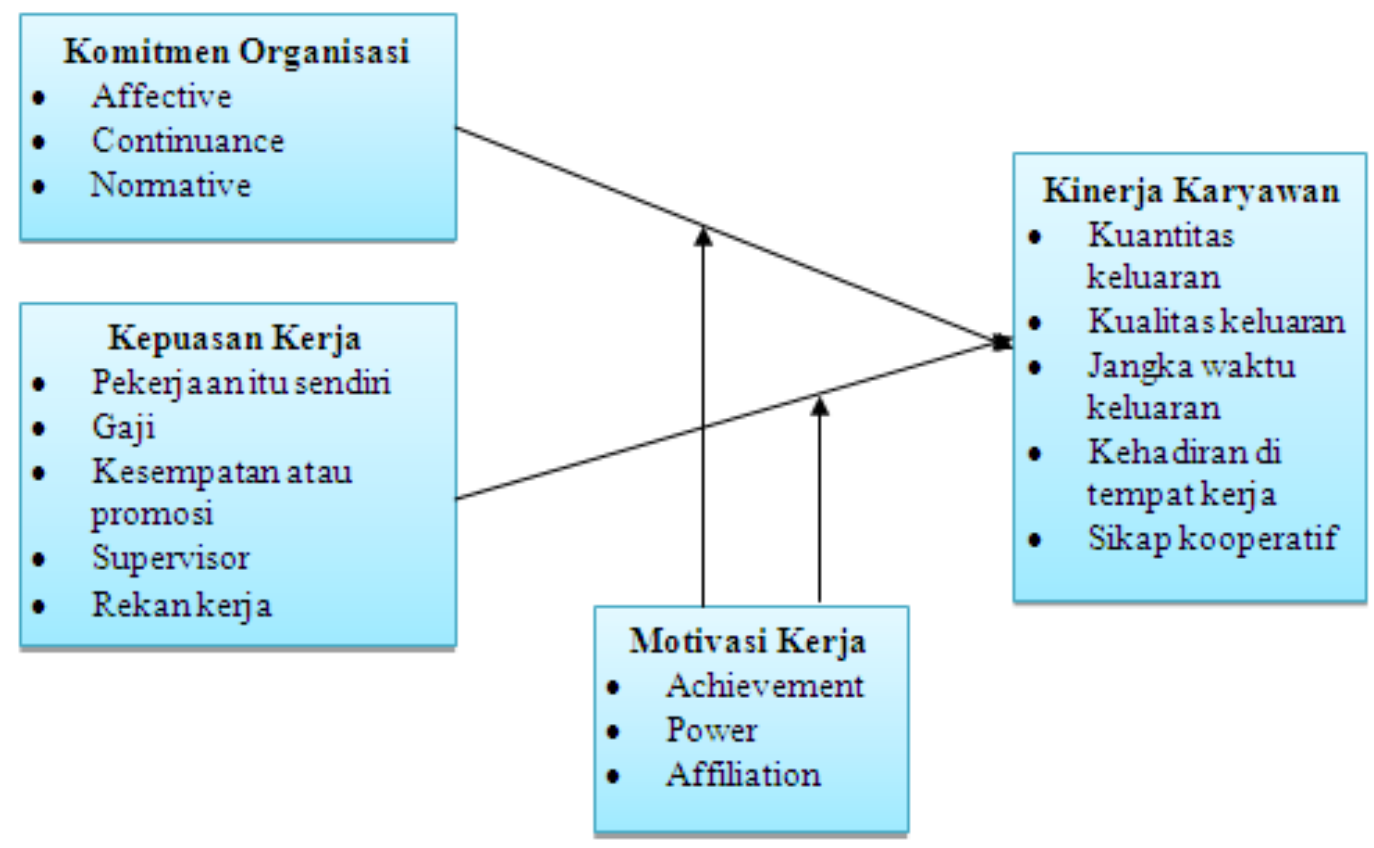

Gambar 3 Kerangka Pemikiran

\section{METODE PENELITIAN}

Penelitian ini menggunakan penelitian deskriptif yang bersifat asosiatif. Unit analisis pada penelitian ini adalah individu, yaitu para karyawan PT. PLN (Persero) distribusi Jakarta Raya dan Tangerang. Horizon waktu untuk penelitian ini adalah cross-sectional, data dari masing-masing responden hanya sekali dikumpulkan dalam rangka menjawab pertanyaan penelitian. 
Tabel 1 Operasionalisasi Variabel

\begin{tabular}{|c|c|c|c|c|}
\hline Variabel & Definisi & Dimensi & Indikator & Skala \\
\hline \multirow[t]{5}{*}{$\begin{array}{l}\text { Kepuasan Kerja } \\
\text { (Gibson,2009) }\end{array}$} & \multirow[t]{5}{*}{$\begin{array}{l}\text { Kepuasan kerja erat } \\
\text { kaitannya dengan } \\
\text { sikap karyawan } \\
\text { terhadap pekerjaannya }\end{array}$} & $\begin{array}{l}\text { Pekerjaan itu } \\
\text { sendiri }\end{array}$ & $\begin{array}{ll} & \text { Pekerjaan yang menarik } \\
\text { - } & \text { Kesempatan untuk mengerjakan } \\
& \text { dengan "cara" sendiri } \\
\text { - } & \text { Keahlian dan ketrampilan memadai }\end{array}$ & $\begin{array}{l}\text { Likert } \\
1 \text { sd } 5\end{array}$ \\
\hline & & Gaji & $\begin{array}{ll}\text { - } & \text { Gaji setara dengan jumlah } \\
\text { pekerjaan } \\
\text { • } \quad \text { Bekerja lebih keras } \\
\end{array}$ & \\
\hline & & $\begin{array}{l}\text { Kesempatan atau } \\
\text { promosi }\end{array}$ & $\begin{array}{ll}- & \text { Kesempatan menjadi seseorang } \\
\text { yang diperhitungkan } \\
\text { • } \\
\text { Peluang untuk belajar keterampilan } \\
\text { baru } \\
\text { • } \quad \text { Kebebasan untuk menilai } \\
\end{array}$ & \\
\hline & & Supervisor & $\begin{array}{l}\text { - } \quad \text { Cara atasan menangani para } \\
\text { pekerjanya } \\
\text { - } \quad \text { Kemampuan atasan dalam } \\
\text { membuat sebuah keputusan }\end{array}$ & \\
\hline & & Rekan kerja & $\begin{array}{l}\text { Kesempatan untuk melakukan } \\
\text { banyak hal bagi karyawan lain } \\
\text { - } \quad \text { Cara teman kerja berhubungan }\end{array}$ & \\
\hline \multirow[t]{3}{*}{$\begin{array}{l}\text { Komitmen } \\
\text { Organisasi (Allen } \\
\text { dan Meyer, 1997) }\end{array}$} & \multirow{3}{*}{$\begin{array}{l}\text { Komitmen dalam } \\
\text { berorganisasi } \\
\text { merupakan } \\
\text { karakteristik } \\
\text { hubungan anggota } \\
\text { organisasi dengan } \\
\text { organisasinya dan } \\
\text { memiliki implikasi } \\
\text { terhadap keputusan } \\
\text { individu untuk } \\
\text { melanjutkan } \\
\text { keanggotaannya } \\
\text { dalam berorganisasi }\end{array}$} & Affectif & $\begin{array}{ll}- & \text { Masalah dalam organisasi } \\
\text { - } & \text { Menghabiskan sisa karir } \\
\text { - } & \text { Terikat secara emosional } \\
\end{array}$ & $\begin{array}{l}\text { Likert } \\
\text { 1sd } 5\end{array}$ \\
\hline & & Continuance & $\begin{array}{l}\text { - } \\
\text { - } \\
\text { Mengacaukan hidup dengan } \\
\text { meninggalkan organisasi } \\
\text { - } \quad \begin{array}{l}\text { Bertahan dalam organisasi } \\
\text { merupakan kebutuhan }\end{array} \\
\end{array}$ & \\
\hline & & Normative & $\begin{array}{ll}\text { - } & \text { Bersalah meninggalkan organisasi } \\
\text { - } & \text { Kesetiaan } \\
\text { Berhutang banyak hal pada } \\
\text { organisasi }\end{array}$ & \\
\hline \multirow[t]{3}{*}{$\begin{array}{l}\text { Motivasi Kerja } \\
\text { (McClelland) }\end{array}$} & \multirow{3}{*}{$\begin{array}{l}\text { Motivasi adalah } \\
\text { kondisi yang } \\
\text { menggerakkan diri } \\
\text { pegawai yang terarah } \\
\text { untuk mencapai } \\
\text { tujuan organisasi }\end{array}$} & Achievement & $\begin{array}{ll}\text { - } & \text { Pencapaian yang dilakukan } \\
\text { Berkontribusi dengan cara yang } \\
\text { positif }\end{array}$ & $\begin{array}{l}\text { Likert } \\
1 \text { sd } 5\end{array}$ \\
\hline & & Power & $\begin{array}{ll}\text { - } & \text { Kenaikan karir } \\
\text { - } & \text { Penghargaan } \\
\end{array}$ & \\
\hline & & Affiliation & $\begin{array}{ll}\text { - } & \text { Rekan kerja ramah } \\
\text { - } & \text { Mudah beradaptasi } \\
\end{array}$ & \\
\hline \multirow{5}{*}{$\begin{array}{l}\text { Kinerja } \\
\text { Karyawan } \\
\text { (Mathis dan } \\
\text { Jackson, 2006) }\end{array}$} & \multirow{5}{*}{$\begin{array}{l}\text { Kinerja pada dasarnya } \\
\text { adalah apa yang } \\
\text { dilakukan dan tidak } \\
\text { dilakukan karyawan }\end{array}$} & $\begin{array}{l}\text { Kuantitas } \\
\text { keluaran }\end{array}$ & $\begin{array}{ll}- & \text { Melebihi target } \\
\text { - } & \text { Menyelesaikan tugas dalam satu } \\
& \text { waktu } \\
\end{array}$ & $\begin{array}{l}\text { Likert } \\
1 \text { sd } 5\end{array}$ \\
\hline & & Kualitas keluaran & $\begin{array}{ll}\text { - } & \text { Pencapaian target kerja } \\
\text { - } & \text { Keakuratan dan ketepatan }\end{array}$ & \\
\hline & & $\begin{array}{l}\text { Jangka waktu } \\
\text { keluaran }\end{array}$ & $\begin{array}{ll}\text { - } & \text { Tugas rutin } \\
\text { - } & \text { Tugas mendadak }\end{array}$ & \\
\hline & & $\begin{array}{l}\text { Kehadiran di } \\
\text { tempat kerja }\end{array}$ & $\begin{array}{ll}\text { - } & \text { Keterlambatan } \\
\text { - } & \text { Absen } \\
\end{array}$ & \\
\hline & & Sikap kooperatif & $\begin{array}{ll}\text { - } & \text { Mengikuti instruksi } \\
\text { - } & \text { Berkoordinasi dengan baik }\end{array}$ & \\
\hline
\end{tabular}

\section{Teknik Pengumpulan Data}

Pengumpulan data dan informasi yang diperlukan dalam penelitian ini menggunakan kuesioner. Kuesioner adalah daftar pertanyaan tertulis yang telah dirumuskan sebelumnya yang akan dijawab responden, biasanya dalam alternatif yang didefinisikan dengan jelas (Sekaran, 2006). 


\section{Teknik Pengambilan Sampel}

Populasi dalam penelitian ini adalah Karyawan Kantor Distribusi PT. PLN (Persero) Distribusi Jakarta Raya dan Tangerang yang terdiri dari enam bidang kerja, yaitu Bidang Perencanaan, Bidang Niaga, Bidang Distribusi, Bidang Keuangan, Bidang Sumber Daya Manusia dan Organisasi, dan Bidang Komunikasi Hukum dan Administrasi sebanyak 250 orang karyawan, dan dengan rumus Slovin diperoleh sampel sebanyak 160 orang responden.

\section{Metode Analisis}

\section{Uji Asumsi Klasik}

Sebelum melakukan pengujian hipotesis, terlebih dahulu akan dilakukan pengujian terjadinya penyimpangan terhadap asumsi klasik. Dalam asumsi klasik terdapat beberapa pengujian yang harus dilakukan, yakni Uji Multikolonieritas, Uji Heterosdastisitas, dan Uji Normalitas.

Salah satu metode untuk mendiagnosis adanya multicollinearity adalah dengan menganalisis nilai tolerance dan lawannya variance inflation factor (VIF). Nilai tolerance yang rendah sama dengan nilai VIF tinggi (VIF=1/tolerance) dan menunjukkan adanya kolinieritas yang tinggi. Nilai yang umum dipakai adalah nilai tolerance 0,10 atau sama dengan nilai VIF di atas 10. tingkat kolinieritas yang dapat ditolerir adalah nilai tolerance 0,10 sama dengan tingkat multikolinieritas 0,95 (Ghozali, 2011).

Tujuan dari pengujian homoskesdastisitas adalah untuk menguji jika dalam model regresi terjadi ketidaksamaan variance dari residual satu pengamatan ke pengamatan lainnya. Model regresi yang baik adalah yang homoskesdastisitas, yakni variance dari residual satu pengamatan ke pengamatan lain bersifat tetap (Ghozali, 2011).

Uji normalitas bertujuan untuk menguji apakah dalam model regresi variabel pengganggu atau residual memiliki distribusi normal. Ada dua cara untuk mendeteksi jika residual berdistribusi normal atau tidak, yaitu dengan analisis grafik dan uji statistik (Ghozali, 2011).

\section{Analisis Regresi}

Dalam penelitian ini perhitungan statistik menggunakan Model Analisis Regresi dengan persamaan sebagai berikut.

$$
\mathbf{Y}=\mathbf{a}+\mathbf{b} 1 \mathrm{X} 1+\mathbf{b} 2 \mathrm{X} 2+\mathbf{b} 3 \mathrm{X} 3
$$

$$
\begin{array}{ll}
\text { Keterangan: } & \mathrm{Y}=\text { Kinerja karyawan } \\
\mathrm{X} 1=\text { Kepuasan kerja karyawan } \\
\mathrm{X} 2=\text { Komitmen organisasi } \\
\mathrm{X} 3=\text { Motivasi kerja } \\
\mathrm{a}=\text { Konstanta (Intercept) } \\
\text { b1, b2, b3 = Koefisien regresi }
\end{array}
$$

Untuk menguji adanya pengaruh variabel motivasi kerja dalam hubungan antara kepuasan kerja dan komitmen organisasi terhadap kinerja karyawan dengan persamaan regresi melalui uji interaksi atau sering disebut dengan Moderated Regresion Analysis (MRA). MRA merupakan aplikasi khusus regresi berganda linier yang dalam persamaan regresinya mengandung unsur interaksi (perkalian dua atau lebih variabel independen) sebagai berikut (Ghozali, 2011). 
Dalam penelitian ini, model regresi moderasi yang akan di uji akan terbagi menjadi dua. Persamaan regresi model pertama dapat dirumuskan sebagai berikut.

$$
\mathbf{Y}=\mathbf{a}+\mathbf{b} 1 \mathrm{X} 1+\mathbf{b} 2 \mathrm{X} 2+\mathbf{b} 3 \mathrm{X} 1 \mathrm{X} 2
$$

Keterangan: $\quad \mathrm{Y}=$ Kinerja karyawan

$\mathrm{X} 1=$ Kepuasan kerja karyawan

$\mathrm{X} 2$ = Motivasi kerja

$\mathrm{X} 1 \mathrm{X} 2$ = Interaksi X1 dan X2

$\mathrm{a}=$ Konstanta (Intercept)

b1, b2, b3 = Koefisien regresi

Persamaan regresi model kedua dapat dirumuskan sebagai berikut.

$$
\mathrm{Y}=\mathrm{a}+\mathrm{b} 1 \mathrm{X} 1+\mathrm{b} 2 \mathrm{X} 2+\mathrm{b} 3 \mathrm{X} 1 \mathrm{X} 2
$$

Keterangan: $\quad \mathrm{Y}=$ Kinerja karyawan

$\mathrm{X} 1=$ Komitmen organisasi

$\mathrm{X} 2$ = Motivasi kerja

$\mathrm{X} 1 \mathrm{X} 2$ = Interaksi X1 dan X2

$\mathrm{a}=$ Konstanta (Intercept)

b1, b2, b3 = Koefisien regresi

Selain menggunakan kriteria tingkat signifikansi koefisien regresi variabel interaksi dalam penentuan variabel moderating, maka untuk mengidentifikasi dan menganalisis variabel moderating secara lebih detail dapat menggunakan framework yang diajukan oleh Sharma (1981), dalam Ghozali (2011) dengan merujuk pada persamaan regresi berikut ini.

$$
\mathrm{Y}=\mathrm{a}+\beta 1 \mathrm{X} 1+\beta 2 \mathrm{X} 2+\beta 3 \mathrm{X1X} 2+\mathrm{e}
$$

Persamaan tersebut dirumuskan ke dalam tabel berikut ini.

Tabel 2 Jenis-jenis Variabel Moderator

\begin{tabular}{lcc}
\hline & $\begin{array}{c}\text { Berhubungan dengan kriterion dan } \\
\text { atau prediktor } /(\beta 2 \text { signifikan) }\end{array}$ & $\begin{array}{c}\text { Tidak berhubungan dengan } \\
\text { kriterion dan prediktor } / \\
\left(\beta^{2} \text { 2 tidak signifikan) }\right.\end{array}$ \\
\hline $\begin{array}{l}\text { Tidak berinteraksi dengan prediktor } \\
/(\beta 3 \text { tidak signifikan) }\end{array}$ & $\begin{array}{c}1 \\
\text { Intervening, Exogen, Antesedent, } \\
\text { Prediktor }\end{array}$ & $\begin{array}{c}\text { Moderator } \\
\text { (Homologizer) }\end{array}$ \\
\hline $\begin{array}{l}\text { Berinteraksi dengan prediktor / } \\
(\beta 3 \text { signifikan) }\end{array}$ & $\begin{array}{c}3 \\
\text { Moderator } \\
\text { (Quasi Moderator) }\end{array}$ & $\begin{array}{c}4 \\
\text { Moderator } \\
\text { (Pure Moderator) }\end{array}$ \\
\hline
\end{tabular}

(Sumber: Sharma (1981) dalam Ghozali (2011:224))

\section{HASIL DAN PEMBAHASAN}

\section{Deskripsi Responden}

Responden yang diambil dalam penelitian ini adalah sebanyak 160 orang; ada 36 orang (23\%) responden yang memiliki masa kerja kurang dari 5 tahun, 9 orang (6\%) responden memiliki masa kerja 5-9 tahun, 39 orang (24\%) responden dengan masa kerja 10-19 tahun, dan 50 orang (31\%) responden yang memiliki masa kerja 20-30 tahun, serta 25 orang (16\%) responden yang memiliki masa kerja di atas 30 tahun. 


\section{Masa Kerja}

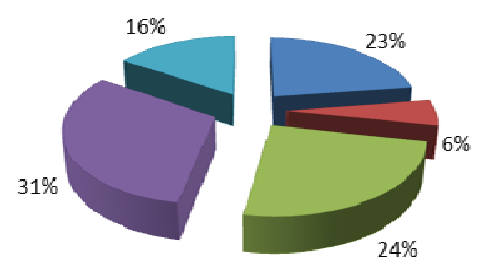

$\square<5$ tahun $\square 5-9$ tahun $\square 10-19$ tahun $\square 20-30$ tahun $\square>30$ tahun

Gambar 4 Deskripsi Responden Berdasarkan Masa Kerja

(Sumber: Peneliti, 2012)

Gambar 5 menunjukkan bahwa mayoritas dari responden berpendidikan terakhir S-1, yaitu sebanyak 62 orang (39\%) responden, SLTA sebanyak 39 orang (24\%), kemudian D-3 sebanyak 38 orang (24\%), D-1 sebanyak 1 orang (10\%) responden, dan karyawan dengan pendidikan S-2 sebanyak 4 orang (2\%) responden. Hanya karyawan dengan pendidikan akhir D-2 yang berjumlah 1 orang (1\%).

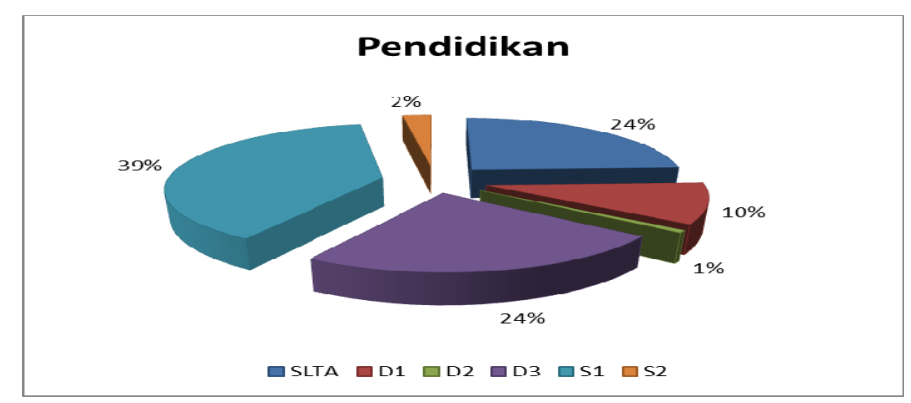

Gambar 5 Deskripsi Responden Berdasarkan Pendidikan (Sumber: Peneliti, 2012)

\section{Uji Asumsi Klasik}

Pengujian normalitas data dilakukan dengan menggunakan Kolmogorof-Smirnof Test pada alpha sebesar 5\%, dengan menggunakan bantuan program SPSS. Dari pengujian terdebut, diperoleh hasil sebagai berikut.

Tabel 3 Test of Normality Keempat Variabel

\begin{tabular}{lrrrrrr}
\hline & \multicolumn{3}{c}{ Kolmogorov-Smirnov $^{\mathbf{a}}$} & \multicolumn{3}{c}{ Shapiro-Wilk } \\
\cline { 2 - 7 } & Statistic & \multicolumn{1}{c}{ df } & \multicolumn{1}{c}{ Sig. } & Statistic & \multicolumn{1}{c}{ df } & \multicolumn{1}{c}{ Sig. } \\
\hline Kepuasan & .067 & 160 & .079 & .982 & 160 & .035 \\
Motivasi & .070 & 160 & .053 & .967 & 160 & .001 \\
Komitmen & .067 & 160 & .080 & .977 & 160 & .009 \\
Kinerja & .069 & 160 & .063 & .972 & 160 & .003
\end{tabular}

a. Lilliefors Significance Correction

Dari hasil pengujian data di atas, diketahui nilai Kolmogorof-Smirnof Test pada empat variabel yang diuji lebih besar dari alpha $(0,05)$. Ini menunjukkan masing-masing data berdistribusi normal. 
Uji multikolinearitas bertujuan untuk menguji jika dalam model regresi terdapat korelasi antarvariabel bebas.

Tabel 4 Uji Multikolinieritas Variabel Independen

\begin{tabular}{|c|c|c|c|}
\hline \multicolumn{4}{|c|}{ Coefficients $^{\mathrm{a}}$} \\
\hline \multirow{2}{*}{ Model } & & \multicolumn{2}{|c|}{ Collinearity Statistics } \\
\hline & & Tolerance & VIF \\
\hline \multirow[t]{3}{*}{1} & Kepuasan & .911 & 1.098 \\
\hline & Motivasi & .859 & 1.164 \\
\hline & Komitmen & .857 & 1.167 \\
\hline
\end{tabular}

a. Dependent Variable: Kinerja

Hasil perhitungan di atas menunjukkan bahwa tidak ada variabel independen yang memiliki nilai tolerance kurang dari 0.10, yang berarti tidak ada korelasi antarvariabel independen. Hasil perhitungan nilai Variance Inflation Factor (VIF) juga menunjukkan hal yang sama, tidak ada satu variabel independen yang memiliki nilai VIF lebih dari 10. Jadi dapat disimpulkan bahwa tidak ada multikolonieritas antarvariabel independen dalam model regresi.

\section{Analisis Regresi}

Pengaruh antara Kepuasan Kerja dan Motivasi Kerja dengan Kinerja Karyawan, dengan H1: kepuasan kerja berpengaruh positif terhadap kinerja karyawan, ditunjukkan dalam tabel sebagai berikut.

Tabel 5 Coefficients Hipotesis Pertama

\begin{tabular}{|c|c|c|c|c|c|c|}
\hline \multirow[t]{2}{*}{ Model } & & \multicolumn{2}{|c|}{$\begin{array}{l}\text { Unstandardized } \\
\text { Coefficients }\end{array}$} & \multirow{2}{*}{$\begin{array}{c}\text { Standardized } \\
\text { Coefficients } \\
\text { Beta }\end{array}$} & \multirow[t]{2}{*}{$\mathbf{t}$} & \multirow[t]{2}{*}{ Sig. } \\
\hline & & B & Std. Error & & & \\
\hline \multirow[t]{2}{*}{1} & (Constant) & 2.496 & .299 & & 8.343 & .000 \\
\hline & Kepuasan & .502 & .075 & .472 & 6.736 & .000 \\
\hline
\end{tabular}

a. Dependent Variable: Kinerja

Tabel 6 Model Summary Hipotesis Pertama

\begin{tabular}{lrrrr} 
Model & R & R Square & \multicolumn{1}{c}{$\begin{array}{c}\text { Adjusted R } \\
\text { Square }\end{array}$} & $\begin{array}{l}\text { Std. Error of } \\
\text { the Estimate }\end{array}$ \\
\hline 1 & $.472^{\mathrm{a}}$ & .223 & .218 & .45264 \\
\hline
\end{tabular}

a. Predictors: (Constant), kepuasan

Pengujian hipotesis yang dilakukan menunjukkan bahwa ada pengaruh positif antara kepuasan kerja dengan kinerja karyawan, dengan nilai signifikansi variabel kepuasan kerja karyawan terhadap kinerja karyawan sebesar 0,000. Dengan demikian, dapat dikatakan variabel Kepuasan Kerja Karyawan berpengaruh signifikan terhadap Kinerja karyawan (Sig. $<0,05)$ dengan nilai kontribusi sebesar 22,3\%.

Hasil ini mendukung penelitian yang dilakukan oleh Heskett, et al. (1994) dan Way, Sturman, and Raab (2010), bahwa dengan meningkatkan kepuasan kerja karyawan dapat menjadikan karyawan sekaligus kinerja organisasi lebih baik. Oleh karena itu, PT. PLN perlu melakukan usaha-usaha untuk meningkatkan kepuasan kerja karyawan agar kinerja individual yang dihasilkan meningkat dan pada akhirnya berimbas pada peningkatan kinerja organisasi. Sedangkan menurut penelitian yang dilakukan Stewart (2000) dalam Worrell (2004), membantu karyawan untuk mandiri memiliki efek positif yang 
besar terhadap kinerja dan kepuasan kerja. Ketika karyawan merasakan pekerjaan mereka merupakan sesuatu yang membuat mereka bertanggung jawab akan hasilnya nanti, karyawan akan menunjukkan usaha yang lebih baik pada tugas yang harus diselesaikan.

Pengujian pada H2: kepuasan kerja karyawan berpengaruh positif terhadap kinerja karyawan dengan motivasi kerja sebagai variabel moderator adalah seperti dalam tabel berikut ini.

Tabel 7 Model Summary Hipotesis Kedua

\begin{tabular}{lcccc} 
Model & R & R Square & $\begin{array}{c}\text { Adjusted R } \\
\text { Square }\end{array}$ & \multicolumn{2}{c}{$\begin{array}{c}\text { Std. Error of } \\
\text { the Estimate }\end{array}$} \\
1 & $.568^{\text {a }}$ & .323 & .310 & .42527 \\
\hline a. Predictors: (Constant), kepuasan*motivasi, kepuasan, motivasi
\end{tabular}

Dari hasil uji interaksi di atas, diperoleh nilai koefisien korelasi (R) sebesar 0,568 yang berati korelasi yang dihasilkan cukup kuat serta koefisien determinasi $\left(\mathrm{R}^{2}\right)$ sebesar 0,323 yang berarti variabel kinerja karyawan dipengaruhi oleh variabel kepuasan kerja karyawan, motivasi, dan interaksi antara kepuasan kerja dengan motivasi sebesar 32,3\%.

Tabel 8 Coefficients Hipotesis Kedua

\begin{tabular}{rlrrrrrr}
\hline \multirow{2}{*}{ Model } & & \multicolumn{2}{c}{$\begin{array}{c}\text { Unstandardized } \\
\text { Coefficients }\end{array}$} & \multicolumn{2}{c}{$\begin{array}{c}\text { Standardized } \\
\text { Coefficients }\end{array}$} & t & \multirow{2}{*}{ Sig. } \\
\cline { 3 - 6 } & & \multicolumn{1}{c}{ B } & Std. Error & Beta & & \\
\hline 1 & (Constant) & 5.159 & 1.677 & & 3.076 & .002 \\
& Kepuasan & -.371 & .407 & -.349 & -.910 & .364 \\
& Motivasi & -.680 & .476 & -.777 & -1.429 & .155 \\
& Kepuasan*Motivasi & .228 & .114 & 1.456 & 1.989 & .058 \\
\hline
\end{tabular}

a. Dependent Variable: Kinerja

Berdasarkan uji signifikansi parameter individual (uji t), dari tiga variabel yang dimasukkan dalam regresi, semuanya mempunyai pengaruh yang tidak signifikan (sig > 0,05), termasuk variabel $\mathrm{X} 1 * \mathrm{X} 2$ yang merupakan interaksi antara kepuasan kerja karyawan dan motivasi kerja. Sehingga dapat disimpulkan sementara bahwa motivasi kerja tidak berpengaruh terhadap hubungan antara kepuasan kerja karyawan, dan kinerja karyawan. Atau dengan kata lain variabel motivasi kerja bukanlah variabel moderating.

Seperti yang telah dijelaskan dalam pembahasan, regresi dengan variabel interaksi umumnya menimbulkan masalah karena terjadi multikolinieritas yang tinggi antarvariabel independen. Begitu juga dengan hasil uji interaksi di atas, setelah dilakukan analisis multikolinieritas (collinearity diagnostic) diperoleh hasil sebagai berikut.

Tabel 9 Uji Multikolinieritas Variabel Interaksi

\begin{tabular}{llrr}
\hline \multirow{2}{*}{ Model } & & \multicolumn{2}{c}{ Collinearity Statistics } \\
\cline { 3 - 4 } & & Tolerance & \multicolumn{1}{c}{ VIF } \\
\hline \multirow{2}{*}{1} & Kepuasan & .030 & 33.772 \\
\cline { 2 - 4 } & Motivasi & .015 & 68.132 \\
\cline { 2 - 4 } & Kepuasan*Motivasi & .008 & 123.373 \\
\hline
\end{tabular}

a. Dependent Variable: Kinerja 
Dari hasil pengujian Multikolinieritas di atas, diketahui bahwa untuk semua variabel independen dalam penelitian ini menunjukkan nilai Tolerance lebih kecil dari 0,10. Demikian juga untuk nilai Variance Inflation Factor (VIF) semuanya jauh lebih besar dari 10. Dengan demikian, model regresi ini mengalami multikolinieritas antarvariabel independen. Hal ini menimbulkan masalah karena tidak memenuhi kriteria asumsi klasik. Model regresi yang baik seharusnya tidak terjadi korelasi di antara variabel independen (Ghozali, 2011).

Sebagaimana yang telah dijelaskan dalam metode penelitian, bahwa untuk mengatasi masalah multikolinieritas ini, maka data yang digunakan dalam analisis interaksi yaitu data center yakni data asli dikurangi dengan rata-ratanya masing-masing. Adapun hasil uji multikolinieritas setelah data aslinya dikurangi dengan rata-ratanya adalah sebagai berikut.

Tabel 10 Uji Multikolinieritas Variabel Interaksi dengan Data Center

\begin{tabular}{llrr}
\multicolumn{4}{c}{ Coefficients $^{\mathrm{a}}$} \\
\multirow{2}{*}{ Model } & \multicolumn{3}{c}{ Collinearity Statistics } \\
& & Tolerance & VIF \\
\hline 1 & Kepuasan1 & .942 & 1.061 \\
& Motivasi1 & .884 & 1.131 \\
& Kepuasan1*Motivasi1 & .935 & 1.070 \\
\hline
\end{tabular}

a. Dependent Variable: Kinerja1

Dari hasil pengujian multikolinieritas di atas, diketahui bahwa untuk semua variabel independen dalam penelitian ini menunjukkan nilai Tolerance lebih besar dari 0,10. Demikian juga untuk nilai Variance Inflation Factor semuanya bernilai lebih kecil dari 10. Dengan demikian, model regresi dalam penelitian ini tidak terjadi multikolinieritas antarvariabel independennya. Setelah dilakukan uji multikolinieritas, maka selanjutnya kembali dilakukan uji interaksi dengan menggunakan data center. Adapun hasil uji interaksi dengan data center sebagai berikut.

Tabel 11 Model Summary Hipotesis Kedua dengan Data Center

\begin{tabular}{lrrrr}
\multicolumn{5}{c}{ Model Summary } \\
Model & R & R Square & $\begin{array}{c}\text { Adjusted R } \\
\text { Square }\end{array}$ & $\begin{array}{c}\text { Std. Error of } \\
\text { the Estimate }\end{array}$ \\
\hline 1 & $.575^{\mathrm{a}}$ & .331 & .318 & 4.22708 \\
\hline
\end{tabular}

a. Predictors: (Constant), kepuasan1*motivasi1, kepuasan1, motivasi 1

Pada tabel, terlihat perbedaan yang cukup signifikan dengan hasil uji interaksi sebelumnya. Dari tabel 11 tersebut diperoleh nilai koefisien korelasi (R) sebesar 0,575 yang berarti korelasi yang dihasilkan cukup kuat. Serta koefisien determinasi $\left(\mathrm{R}^{2}\right)$ sebesar 0,331 yang berarti variabel kinerja karyawan dipengaruhi oleh variabel kepuasan kerja karyawan, motivasi, dan interaksi antara kepuasan kerja dengan motivasi sebesar 33,1\%.

Tabel 12 Coefficients Hipotesis Kedua dengan Data Center

\begin{tabular}{llrrrrrr}
\hline \multirow{2}{*}{ Model } & & \multicolumn{2}{c}{$\begin{array}{c}\text { Unstandardized } \\
\text { Coefficients }\end{array}$} & \multicolumn{2}{c}{$\begin{array}{c}\text { Standardized } \\
\text { Coefficients }\end{array}$} & t & Sig. \\
\cline { 3 - 5 } & & \multicolumn{2}{c}{ B } & Std. Error & Beta & & \\
\hline 1 & (Constant) & -.158 & .342 & & -.461 & .645 \\
& Kepuasan1 & .367 & .060 & .415 & 6.147 & .000 \\
& Motivasi1 & .381 & .101 & .262 & 3.757 & .000 \\
& Kepuasan1*Motivasi1 & .034 & .016 & .146 & 2.150 & .033 \\
\hline
\end{tabular}


Berbeda dengan uji interaksi sebelumnya yang semua variabel independennya mempunyai pengaruh tidak signifikan (sig > 0,05), hasil uji interaksi yang menggunakan data center menunjukkan ketiga variabel yang dimasukkan ke persamaan berpengaruh signifikan. Sehingga dapat disimpulkan bahwa variabel motivasi kerja merupakan variabel moderator bagi kepuasan kerja karyawan terhadap kinerja karyawan. Hal ini sekaligus mendukung hipotesis 2 yang menyatakan bahwa kepuasan kerja karyawan berpengaruh positif terhadap kinerja karyawan dengan motivasi kerja sebagai variabel moderator. Jadi dapat diperoleh persamaan regresi moderasi dari Model pertama sebagai berikut.

$$
Y=-0,158+0,367 X 1+0,381 X 2+0,034 X 1 X 2
$$

Selain itu, dari hasil pengujian statistik di atas, dapat disimpulkan bahwa variabel motivasi kerja dapat bertindak sebagai variabel independen (bebas) sekaligus variabel moderator bagi kepuasan kerja karyawan dengan kinerja karyawan. Hal ini dapat menjadi sebuah masukan bagi perusahaan bahwa untuk dapat meningkatkan kinerja karyawan, perusahaan dapat berupaya meningkatkan motivasi kerja para karyawan yang kemudian akan berimbas pada kepuasan kerja karyawan itu.

Motivasi dirasa penting karena jika karyawan tidak termotivasi untuk melakukan pekerjaannya dengan baik, turnover akan meningkat. Setelah itu karyawan akan menjadi frustasi, dan akhirnya menjadi tidak produktif. Tidak produktifnya karyawan secara individual dapat memengaruhi kinerja organisasi secara keseluruhan (Robbins, 2007; Parsons dan Broadbridge, 2006; dan Hong dan Waheed, 2011).

Menurut Tella, Ayeni, dan Poppola (2007), untuk meningkatkan motivasi kerja dan kepuasan kerja karyawan, atasan sebaiknya memberi karyawan tugas yang lebih menantang dengan tambahan tanggung jawab dan wewenang untuk menyelesaikannya. Hal ini akan secara otomatis meningkatkan kinerja mereka terhadap organisasi.

Pengaruh antara komitmen organisasi dan motivasi kerja dengan kinerja karyawan pada H3: komitmen organisasi bepengaruh positif terhadap kinerja karyawan adalah seperti pada tabel berikut.

Tabel 13 Coefficients Hipotesis Ketiga

\begin{tabular}{|c|c|c|c|c|c|c|}
\hline \multirow{2}{*}{ Model } & & \multicolumn{2}{|c|}{$\begin{array}{c}\text { Unstandardized } \\
\text { Coefficients }\end{array}$} & $\begin{array}{c}\text { Standardized } \\
\text { Coefficients }\end{array}$ & \multirow{2}{*}{$\mathbf{t}$} & \multirow{2}{*}{ Sig. } \\
\hline & & B & $\begin{array}{l}\text { Std. } \\
\text { Error }\end{array}$ & Beta & & \\
\hline \multirow[t]{2}{*}{1} & (Constant) & 3.906 & .221 & & 17.686 & .000 \\
\hline & Komitmen & .189 & .070 & .211 & 2.716 & .007 \\
\hline
\end{tabular}

a. Dependent Variable: Kinerja

Pengujian hipotesis yang dilakukan menunjukkan bahwa ada pengaruh positif antara komitmen organisasi dengan kinerja karyawan dengan nilai signifikansi sebesar 0,000. Dengan demikian dapat dikatakan variabel komitmen organisasi berpengaruh signifikan terhadap kinerja karyawan (Sig. < 0,05 ) dengan nilai kontribusi sebesar 4,5\%. Hasil ini mendukung penelitian yang dilakukan oleh Bentein, et al. (2005); Jaros, et al. (1993); Luchak and Gellatly (2007); Meyer, Becker, and Vandenberghe (2004); dan Harrison dan Hubard (1998) dalam Devi (2009) yang menyatakan bahwa karyawan yang memiliki keterlibatan tinggi dalam bekerja (komitmen) tidak mempunyai keinginan untuk keluar dari perusahaan dan ini merupakan modal dasar untuk mendorong produktivitas ke arah yang lebih tinggi.

Pengujian H4: komitmen organisasi berpengaruh positif terhadap kinerja karyawan dengan motivasi kerja sebagai variabel moderator secara simultan adalah sebagai berikut. 
Tabel 14 Anova Hipotesis Keenam dengan Data Center

\begin{tabular}{llrrrrr}
\hline Model & & Sum of Squares & df & Mean Square & F & Sig. \\
\hline 1 & Regression & 698.696 & 3 & 232.899 & 10.482 & $.000^{\mathrm{a}}$ \\
& Residual & 3466.296 & 156 & 22.220 & & \\
& Total & 4164.992 & 159 & & & \\
\hline
\end{tabular}

a. Predictors: (Constant), komitmen1*motivasi1, motivasi1, komitmen1

b. Dependent Variable: kinerja1

Demikian juga dengan hasil uji Anova atau $\mathrm{F}$ test yang menggunakan data center menghasilkan nilai signifikansi 0,000 . Karena probabilitas signifikansi jauh lebih kecil dari 0,05, model regresi dapat digunakan untuk memprediksi efektivitas kinerja karyawan atau dapat dikatakan bahwa secara bersama-sama semua variabel independen dan variabel moderating berpengaruh signifikan terhadap efektivitas kinerja karyawan.

Tabel 15 Coefficients Hipotesis Ketiga dengan Data Center

\begin{tabular}{|c|c|c|c|c|c|c|}
\hline \multirow{2}{*}{\multicolumn{2}{|c|}{ Model }} & \multicolumn{2}{|c|}{$\begin{array}{c}\text { Unstandardized } \\
\text { Coefficients }\end{array}$} & \multirow{2}{*}{$\begin{array}{c}\begin{array}{c}\text { Standardized } \\
\text { Coefficients }\end{array} \\
\text { Beta } \\
\end{array}$} & \multirow[t]{2}{*}{$\mathbf{t}$} & \multirow[t]{2}{*}{ Sig. } \\
\hline & & B & Std. Error & & & \\
\hline \multirow[t]{4}{*}{1} & (Constant) & -.098 & .386 & & -.254 & .800 \\
\hline & Komitmen1 & .080 & .089 & .072 & .893 & .373 \\
\hline & Motivasi1 & .511 & .115 & .350 & 4.450 & .000 \\
\hline & Komitmen1*Motivasi1 & .018 & .019 & .076 & .972 & .333 \\
\hline
\end{tabular}

a. Dependent Variable: Kinerja1

Tiga variabel independen yang dimasukkan dalam persamaan regresi, ternyata hanya variabel motivasi kerja yang mempunyai pengaruh yang signifikan (sig $>0,05)$ terhadap kinerja karyawan. Sedangkan untuk variabel komitmen organisasi dan interaksi antara komitmen organisasi dengan motivasi kerja tidak memiliki pengaruh signifikan secara individual terhadap kinerja karyawan. Ini terlihat dari nilai signifikansi masing-masing variabel yakni sebesar 0,373 dan 0,333 yang jauh lebih besar jika dibandingkan dengan 0,05 . Hal ini sekaligus menolak hipotesis 4 yang menyatakan bahwa komitmen organisasi berpengaruh positif terhadap kinerja karyawan dengan motivasi kerja sebagai variabel moderator. Jadi dapat diperoleh persamaan regresi moderasi dari model kedua sebagai berikut.

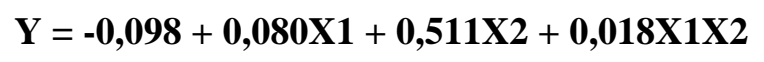

Pengaruh antara kepuasan kerja karyawan, komitmen organisasi dan motivasi kerja dengan kinerja karyawan dengan H5: komitmen organisasi, motivasi kerja, dan kepuasan kerja karyawan secara bersama-sama berpengaruh positif terhadap kinerja karyawan secara simultan adalah sebagai berikut.

Tabel 16 Coefficients

\begin{tabular}{|c|c|c|c|c|c|c|}
\hline \multirow[t]{2}{*}{ Model } & & \multicolumn{2}{|c|}{$\begin{array}{c}\text { Unstandardized } \\
\text { Coefficients }\end{array}$} & \multirow{2}{*}{$\begin{array}{c}\begin{array}{c}\text { Standardized } \\
\text { Coefficients }\end{array} \\
\text { Beta } \\
\end{array}$} & \multirow[t]{2}{*}{$\mathbf{t}$} & \multirow[t]{2}{*}{ Sig. } \\
\hline & & B & Std. Error & & & \\
\hline \multirow[t]{4}{*}{1} & (Constant) & 1.866 & .328 & & 5.682 & .000 \\
\hline & Kepuasan & .424 & .074 & .398 & 5.700 & .000 \\
\hline & Motivasi & .256 & .063 & .292 & 4.060 & .000 \\
\hline & Komitmen & .012 & .065 & .014 & .193 & .847 \\
\hline
\end{tabular}

a. Dependent Variable: Kinerja 
Tabel 17 Anova

\begin{tabular}{llrrrrr}
\hline Model & & Sum of Squares & df & Mean Square & \multicolumn{1}{c}{ F } & \multicolumn{1}{c}{ Sig. } \\
\hline 1 & Regression & 12.746 & 3 & 4.249 & 22.916 & $.000^{\mathrm{a}}$ \\
& Residual & 28.922 & 156 & .185 & & \\
& Total & 41.668 & 159 & & & \\
\hline
\end{tabular}

a. Predictors: (Constant), kepuasan, motivasi, komitmen

b. Dependent Variable: kinerja

Tabel 18. Model Summary

\begin{tabular}{lcccc} 
Model & R & R Square & $\begin{array}{c}\text { Adjusted R } \\
\text { Square }\end{array}$ & $\begin{array}{c}\text { Std. Error of the } \\
\text { Estimate }\end{array}$ \\
\hline 1 & $.553^{\text {a }}$ & .306 & .293 & .43058 \\
\hline a. Predictors: (Constant), kepuasan, motivasi, komitmen &
\end{tabular}

Pengujian hipotesis yang dilakukan secara individual menunjukkan bahwa ada pengaruh positif antara motivasi kerja dan kepuasan kerja karyawan terhadap kinerja karyawan (Sig. < 0,05). Namun hasil sebaliknya ditunjukkan oleh komitmen organisasi terhadap kinerja karyawan dengan nilai signifikansi sebesar 0,847 yang jauh diatas 0,05. Selain itu, dari uji ANOVA atau F test didapat nilai signifikansi sebesar 0,000 yang menyatakan variabel komitmen organisasi, motivasi kerja, dan kepuasan kerja karyawan jika dilihat secara simultan berpengaruh signifikan terhadap Kinerja karyawan dengan nilai kontribusi sebesar 30,6\%. Dari hasil penelitian ini, kepuasan kerja diketahui memiliki pengaruh yang paling besar terhadap kinerja karyawan dibandingkan dengan kedua variabel bebas lainnya, dimana variabel kepuasan kerja memiliki koefisien beta paling besar. Maka itu, kepuasan kerja merupakan faktor utama yang harus diperhatikan oleh PT PLN untuk dapat mencapai kinerja karyawan. Jadi dapat diperoleh persamaan regresi berganda dari Model ketiga sebagai berikut.

$$
\mathrm{Y}=1,866+0,424 \mathrm{X} 1+0,256 \mathrm{X} 2+0,012 \mathrm{X} 3
$$

\section{SIMPULAN}

Berdasarkan hasil penelitian ini, dapat ditarik kesimpulan sebagai berikut. Pertama, variabel kepuasan kerja berpengaruh signifikan positif terhadap kinerja karyawan. Begitu juga dengan variabel kepuasaan kerja yang dimoderasi motivasi kerja, menunjukkan pengaruh yang signifikan positif terhadap kinerja karyawan baik secara individual maupun simultan. Kedua, variabel komitmen organisasi menunjukkan hasil signifikan positif terhadap kinerja karyawan. Sedangkan variabel komitmen organisasi yang dimoderasi motivasi kerja, menunjukan pengaruh yang signifikan secara simultan terhadap kinerja karyawan, namun tidak signifikan secara individual.

\section{DAFTAR PUSTAKA}

Allen, N. J., dan Meyer, J. P. (1990). The Measurement and Antecedents of Affective, Continuance and Normative Commitment to the Organization. Journal of Occupational Psychology, 63, 118.

Astuti, R. F. (2005). Pengaruh Kepercayaan Pada Atasan, Kepuasan Kerja dan Komitmen Organisasi Terhadap Kinerja Karyawan (Studi Empiris Pada Pegawai Pemkab Kendal). Tesis S2. Semarang: Universitas Diponegoro. 
Devi, E. K. D. (2009). Analisis Pengaruh Kepuasan Kerja dan Motivasi Terhadap Kinerja Karyawan dengan Komitmen Organisasional Sebagai Variabel Intervening. Tesis S2. Semarang: Universitas Diponegoro.

Ghozali, I. (2011). Aplikasi Analisis Multivariate dengan Program IBM SPSS 19. Semarang: Universitas Diponegoro.

Gibson, J. L., Ivancevich, J. M., Donnelly, J. H., dan Konopaske, R. (2009). Organizations: Behavior, Structure, Processes. New York: McGraw - Hill.

Greenberg, J., and Baron, R. A. (2003). Behavior in Organizations. Edisi Delapan. New Jersey: Prentice Hall.

Hong, T. T., and Waheed, A. (2011). Herzberg's Motivation-Hygiene Theory and Job Satisfaction in The Malaysian Retail Sector: The Mediating Effect of Love of Money. Asian Academy of Management Journal, 16(1), 73-94.

Joo, Baek-Kyoo, Lim, T. (2009). The Effects of Organizational Learning Culture, Perceived Job Complexity, and Proactive Personality on Organizational Commitment and Intrinsic Motivation. Journal of Leadership \& Organizational Studies, 16(1), 48-60.

Judge, T. A., Bono, J. E., Thoresen, C. J., and Patton, G. K. (2001). The job satisfaction-job performance relationship: A qualitative and quantitative review. Psychological Bulletin, 127, 376-407.

Kuncoro. (2009). Metode Riset untuk Bisnis \& Ekonomi. Jakarta : Erlangga

Luchak, A. A., and Gellatly, I. R. (2007). A Comparison of Linear and Nonlinear Relations Between Organizational Commitment and Work Outcomes. Journal of Applied Psychology, 92(3), 786793.

Luthans, F. (2006). Perilaku Organisasi. Edisi Sepuluh. Yogyakarta: Andi.

Mathieu, J., and Zajac D.(1990). A Review and Meta Analysis of The Antecedents, Correlates and Consequences of Organizational Commitment. Psychology Bulletin. 108. 171-194. http://www.mendeley.com. Diakses 19 November 2011.

Mathis, R. L., Jackson, J. H. (2006). Human Resources Management. Edisi 10. Jakarta: Salemba empat.

Meyer, T. E. B., and Vandenberghe, C. (2004). Employee Commitment and Motivation: A Conceptual Analysis and Integrative Model. Journal of Applied Psychology, 89(6), 991-1007.

Nurjanah. (2008). Pengaruh Gaya Kepemimpinan dan Budaya Organisasi Terhadap Komitmen Organisasi dalam Meningkatkan Kinerja Karyawan (Studi Pada Biro Lingkup Departemen Pertanian). Tesis S2. Semarang: Universitas Diponegoro.

PT. PLN (Persero) Disjaya dan Tangerang. (2010). Surat Direksi PT PLN (Persero) Distribusi Jakarta Raya dan Tangerang No. 040/482/DISJAYA/2010.

PT. PLN (Persero) Disjaya dan Tangerang. (2011). PLN Disjaya dan Tangerang bersama PUSKOPAL UI membahas survey Malcolm Bridge. http://www.pln.co.id/disjaya/?p=1036. Diakses 10 Januari 2012. 
Riduwan dan Kuncoro. (2008). Cara Menggunakan dan Memakai Analisis Jalur (Path Analysis). Bandung: Alfabeta.

Robbins, S. P. (2007). Manajemen. Edisi kedelapan. Jilid 2. Jakarta: Indeks.

Robbins, S. P., and Judge, T. (2007). Organizational Behavior, Edisi 12. New Jersey: Prentice Hall.

Robinson. (2005). Pengaruh Kualitas Anggaran Terhadap Efektivitas Pengawasan Anggaran : Pengetahuan Tentang Anggran Sebagai Variabel Moderating. Tesis S2. Semarang: Universitas Diponegoro.

Sekaran, U. (2006). Research Methods For Business: Metodologi Penelitian untuk Bisnis. Edisi 4. Jilid 2. Jakarta: Salemba Empat.

Way, S. A., Sturman, M. C., and Raab, C.. (2010). What Matters More? : Contrasting the Effects of Job Satisfaction and Service Climate on Hotel Food and Beverage Managers' Job Performance. Cornell University, 51(3), 379-397. 